\title{
IMPLEMENTASI MODEL PEMBELAJARAN KOOPERATIF TIPE JIRQA TERHADAP KEMAMPUAN BERPIKIR KRITIS SISWA PADA MATERI PERTUMBUHAN DAN PERKEMBANGAN TUMBUHAN
}

\author{
Beni $^{1}$, Yakobus Bustami ${ }^{2}$, Leliavia ${ }^{3}$ \\ ${ }^{1,2,3}$ Program Studi Pendidikan Biologi, STKIP Persada Khatulistiwa, Sintang \\ e-mail: ybustami07@gmail.com
}

\begin{abstract}
ABSTRAK
Keterampilan berpikir kritis siswa di SMP Negeri 2 Sekadau Hilir masih rendah. Penelitian ini bertujuan untuk mengetahui pengaruh model pembelajaran kooperatif tipe jigsaw, membaca, bertanya, menjawab (JiRQA) terhadap keterampilan berpikir kritis siswa SMP Negeri 2 Sekadau Hilir. Pendekatan ini kuantitatif dalam bentuk penelitian eksperimen semu. Instrumen untuk mengukur keterampilan berpikir kritis menggunakan pertanyaan esai sebanyak 6 item. Data dianalisis menggunakan analisis statistik deskriptif untuk menentukan rata-rata dan analisis inferensial menggunakan uji-t. Hasil analisis statistik deskriptif menunjukkan bahwa ada peningkatan nilai ratarata keterampilan berpikir kritis pretest dan posttest dari kelas eksperimen sebesar 45,28\% dan kelas kontrol sebesar $33,11 \%$. Hasil analisis statistik inferensial menunjukkan bahwa nilai probabilitas keterampilan berpikir kritis siswa 0,00 lebih kecil dari 0,05 , sehingga dapat disimpulkan bahwa ada pengaruh yang signifikan penerapan model pembelajaran JiRQA pada keterampilan berpikir kritis siswa.
\end{abstract}

Kata kunci: Keterampilan berpikir kritis, kooperatif, pembelajaran JiRQA, biologi.

\section{ABSTRACT}

The critical thinking skills of students in SMP Negeri 2 Sekadau Hilir were still low. This research aims to determine the effect of the jigsaw, reading, questioning, answering (JiRQA) type cooperative learning model on students critical thinking skills of SMP Negeri 2 Sekadau Hilir. The approach was quantitative in the form of quasiexperiment research. The instrument for measuring critical thinking skills using essay questions as many as 6 items. Data were analyzed using descriptive statistical analysis to determine mean and inferential analysis using the t-test. The results of the descriptive statistical analysis show that there was an increase in the mean value of pretest and post test critical thinking skills of the experimental class by $45.28 \%$ and the control class by $33.11 \%$. The inferential statistical analysis results show that the probability value of students critical thinking skills of 0.00 is smaller than 0.05 so that it can be concluded that there was a significant effect of implementation JiRQA learning model on students' critical thinking skills.

Keyword: Critical thinking skills, cooperative, JiRQA learning, biology.

Submitted: 18 Februari 2019

PENDAHULUAN

Pada abad 21 kita dihadapkan denganberbagai tantangan kehidupan yang membutuhkan kualitas untuk berkompetensi dalam segala bidang,
Accepted: 12 Juni 2019

Published: 05 Juli 2019 
Vol. 04, No. 01 : Hal. 9 - 15

Februari 2019

mengatakan kehidupan di abad 21 menuntut berbagai pendapat atau argumen yang harus di kuasai seseorang, sehingga diharapkan pendidikan dapat mempersiapkan siswa untuk menguasai berbagai kemampuan supaya menjadi pribadi yang sukses dalam hidup. Kesuksesan peserta didik dapat dibentuk melalui proses pendidikan.

Trikasari (2016) berpendapat bahwa pendidikan bukan hanya menyiapkan masa depan, tetapi juga bagaimana menciptakan masa depan. Pendidikan harus mampu mengembangkan potensi peserta didik termasuk membentuk manusia yang kritis agar mampu menghadapi masalah dalam kehidupan sehari-hari. Pendidikan harus mampu menciptakan kualitas sumber daya manusia, salah satunya meningkatkan kemampuan berpikir kritis (Bustami, 2017a).

Kemampuan berpikir kritis memiliki peranan dalam kehidupan global di abad 21 (Bustami et al, 2018). Kemampuan berpikir kritis dapat digunakan sebagai dasar analisis argumen dan wawasan terhadap tiap-tiap makna dan interpretasi semua data untuk mengembangkan penalaran yang logis (Liliasari, 2003: 2) Seseorang yang berpikir kritis akan mampu mengajukan pertanyaan yang tepat, menggabungkan informasi yang relevan, efektif dan efisien, kreatif menyusun informasi, mempunyai nalar yang masuk akal atas informasi yang dimiliki, kesimpulannya konsisten serta dapat dipercaya (Bustami, 2017b: 2). Lebih lanjut, Efendi \& Rokayana (2017: 85), berpikir kritis adalah kemampuan untuk berpendapat dengan cara yang terorganisasi.

Melihat pentingnya peranan berpikir kritis, maka setiap jenjang pendidikan perlu meningkatkan kemampuan berpikir kritis siswa terutama pada siswa Sekolah Menengah Pertama. Namun, fakta
E-ISSN: 2597-9833

menunjukan bahwa kemampuan berpikir kritis siswa pada Sekolah Menengah Pertama masih rendah. Rendahnya berpikir kritis telah diungkapkan oleh Sudin (2018: 4) bahwa nilai rerata kemampuan berpikir kritis siswa Sekolah Menengah Pertama dalam menganalisis, memberikan argumen, dan menarik kesimpulan masih rendah. Hal tersebut dibuktikan $75 \%$ dari total keseluruhan siswa kelas VIII masih mengalami kesulitan dalam memecahkan persoalan belajar. Lebih lanjut, Jumaisayroh dkk, (2014: 158) mengatakan bahwa nilai rata-rata kemampuan berpikir siswa Sekolah Menengah Pertama (SMP) hanya 68 dan masuk kategori cukup.

Rendahnya kemampuan berpikir kritis siswa dikarenakan proses pembelajaran yang masih bersifat konvensional (Bustami, 2017a). Pembelajaran yang bersifat konvensional menjadikan guru sebagai sumber belajar utama sangat membosankan bagi siswa di dalam kelas sehingga tidak akan menumbuhkan rasa ingin tahu siswa tentang materi yang akan disampaikan. Proses pembelajaran cenderung pasif ketika proses pembelajaran sedang berlangsung. Hal ini dikarenakan siswa tidak membaca materi yang akan disampaikan, sehingga pemahaman terhadap bahan bacaan menjadi sangat rendah. Siswa jarang membaca buku, jarang menulis, dan bahkan menjawab pertanyaan. Disisi lain, siswa cenderung berbicara dengan teman sebangkunya daripada mendengar guru menyampaikan materi pelajaran. Siswa tidak memiliki tanggung jawab untuk berperan aktif dalam proses pembelajaran yang sedang berlangsung.

Padahal, kegiatan belajar tidak terlepas dari kegiatan membaca, menulis, dan menjawab pertanyaan. Seorang guru harus mampu menciptakan proses 
Vol. 04, No. 01 : Hal. 9 - 15

Februari 2019

P-ISSN: 2528-679X

E-ISSN: 2597-9833

pembelajaran yang tepat demi tercapainya pembelajaran yang efektif sehingga peserta didik dapat mencapai tujuan pembelajaran. Pembelajaran harus mampu menuntut siswa untuk berkerjasama, aktif, inovatif, dan kreatif serta konstruktivistik sehingga masing-masing siswa dapat berargumen (Suparmi, 2012: 113), salah satunya dengan menerapkan model pembelajaran kooperatif. Model pembelajaran kooperatif adalah pembelajaran yang dilakukan oleh siswa dalam kelompok tertentu untuk mencapai tujuan yang dirumuskan. Model pembelajaran kooperatif mampu menciptakan kontak interpersonal dan saling ketergantungan dengan tujuan bersama.

Salah satu pembelajaran kooperatif, yaitu strategi pembelajaran JiRQA. Strategi pembelajaran JiRQA adalah pengabungan dari dua model strategi pembelajaran yakni Jigsaw dan RQA (Reading, Questioning, Answering) yang saling melengkapi satu sama lain (Bustami, 2017a).

Bustami,

(2017b:

mengungkapkan bahwa adanya kegiatan diskusi dan saling berargumentasi pada
JiRQA akan memunculkan perluasan dan konflik kognitif pada peserta didik, akibatnya peserta didik akan terbiasa untuk berpikir. Lebih lanjut, penelitian Ariyanti dkk (2013: 38) mengungkapkan bahwa peserta didik yang sering dilatih untuk bertukar pikiran, berargumentasi, bertukar informasi, dan memecahkan masalah dalam kelompok diskusi kecilnya maka semakin terbentuk kemampuan peserta didik untuk lebih kritis dan kreatif. Berdasarkan permasalahan tersebut, maka perlu dilakukan penelitian dengan penerapan model pembelajaran kooperatif tipe JiRQA terhadap kemampuan berpikir kritis siswa pada pokok bahasan pertumbuhan dan perkembangan tumbuhan.

\section{METODE PENELITIAN}

Pendekatan dalam penelitian ini, yaitu pendekatan kuantitatif dengan metode quasi experimental. Penelitian ini menggunakan rancangan pretest posttest nonequivalent control groupdesign. Rancanganpretest posttest nonequivalent control group dapat dilihat pada Tabel 1.

Tabel1. Rancangan Penelitian

\begin{tabular}{ccc}
\hline Pretest & Treatment & Posttest \\
\hline $\mathrm{O}_{1}$ & $\mathrm{X}$ & $\mathrm{O}_{2}$ \\
$\mathrm{O}_{3}$ & $\mathrm{Y}$ & $\mathrm{O}_{4}$ \\
\hline
\end{tabular}

Keterangan :

$\mathrm{O}_{1} \quad=$ Pretest kelas eksperimen

$\mathrm{O}_{3} \quad=$ Pretest kelas kontrol

$\mathrm{O}_{2} \quad=$ Posttest kelas eksperimen

$\mathrm{O}_{4} \quad=$ Posttest kelas kontrol

$\mathrm{X} \quad=$ Pembelajaran pada kelas eksperimenmenggunakan model JiRQA

$\mathrm{Y} \quad=$ Pembelajaran pada kelas kontrol

Populasi adalah seluruh siswa yang terdiri dari 56 siswa dengan total sampel 56 siswa, 29 siswa untuk kelas eksperimen dan 27 siswa untuk kelas kontrol. Penentuan sampel dalam penelitian ini diambil secara sampling jenuh, karena semua anggota populasi di ambil sebagai sampel penelitian.
Instrumen yang digunakan berupa soal esay sebanyak enam soal. Soal tes digunakan untuk mengetahui kemampuan berpikir kritis siswa pada materi pertumbuhan dan perkembangan tumbuhan. Soal tes yang digunakan telah divalidasi oleh tim ahli dan diujicoba untuk melihat validitas dan reliabilitas. Hasil uji coba 
Vol. 04, No. 01 : Hal. 9 - 15

Februari 2019

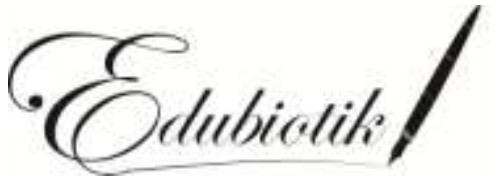

P-ISSN: 2528-679X

E-ISSN: 2597-9833

menunjukan bahwa enam item soal tes valid dan reliabel 0,78 dengan kategori tinggi.

Prosedur dalam penelitian ini terdiri atas tiga tahap. Tahap pertama adalah tahap pemberian pretest, pemberian pretest untuk melihat kemampuan awal siswa sebelum diterapkan model pembelajaran kooperatif tipe JiRQA. Tahap kedua adalah tahap pelaksanaan menggunakan pembelajaran kooperatif tipe JiRQA dalam pembelajaran diterapkan untuk tiga kali pertemuan pada materi pertumbuhan dan perkembangan pada tumbuhan. Kemudian tahap ketiga adalah tahap pemberian posttest, pemberian posttest untuk melihat kemampuan akhir siswa setelah diterapkan model pembelajaran kooperatif tipe JiRQA.

Analisis data menggunakan analisis deskriptif dan analisis inferensial. Analisis deskriptif untuk melihat nilai rerata kemampuan berpikir kritis siswa. Analisis inferensial menggunakan uji t untuk melihat hasil uji hipotesis. Sebelum melakukan uji hipotesis terlebih dahulu dilakukan uji prasyarat, yaitu uji normalitas dan uji homogenitas. Hasil uji normalitas dan homogenitas menunjukan nilai signifikan lebih besar 0,05 sehingga dapat disimpulkan data kemampuan berpikir kritis siswa baik pretest maupun posttest berdistribusi normal dan homogen. Semua data terkait kemampuan berpikir kritis siswa dianalisis dengan menggunakan Program SPSS.

\section{HASIL DAN PEMBAHASAN}

Hasil analisis deskriptif dilakukan untuk mengetahui rerata pada nilai pretest danposttest. Pelaksanaan pretest dan posttest diikuti oleh 29 siswa di kelas eksperimen dan 27 siswa di kelas kontrol. Hasil analisis deskriptif kemampuan berpikir kritis siswa dapat dilihat pada Tabel 2.

Tabel 2. Nilai Kemampuan Berpikir Kritis Siswa

\begin{tabular}{lcccc}
\hline \multirow{2}{*}{ Nilai } & \multicolumn{2}{c}{ Kelas Eksperimen } & \multicolumn{2}{c}{ Kelas Kontrol } \\
\cline { 2 - 5 } & \multicolumn{1}{c}{ Pretest } & Posttest & Pretest & Posttest \\
\hline Nilai Tertinggi & 50,00 & 90,00 & 65,00 & 90,00 \\
Nilai Terendah & 10,00 & 68,00 & 10,00 & 60,00 \\
Nilai Rerata & 43,13 & 79,41 & 38,00 & 71,11 \\
Kategori & Sangat Kurang & Baik & Sangat Kurang & Baik \\
\hline Peningkatan & \multicolumn{2}{c}{33,11} \\
\hline
\end{tabular}

Berdasarkan Tabel 2 terlihat bahwa nilai rerata pretest siswa kelas eksperimen sebesar 34,13 dengan nilai tertinggi sebesar 50 , nilai terendah sebesar 10 , sedangkan nilai rerata posttest sebesar 79,41 dengan nilai tertinggi 90 , nilai terendah 68 , pada kelas kontrol diperoleh nilai rerata pretest sebesar 38 dengan nilai tertinggi 65, nilai terendah 10. Pada posttest diperoleh rerata sebesar 71,11. Nilai tertinggi 90, nilai terendah 60. Nilai rerata kemampuan berpikir kritis siswa pada kelas eksperimen mengalami peningkatan sebesar 45,28 sedangkan untuk kelas kontrol mengalami peningkatan sebesar 33,11.
Hasil penelitian ini sejalan dengan hasil penelitian yang dilakukan oleh Bustami (2017a) bahwa penerapan pembelajaran JiRQA lebih mampu meningkatkan kemampuan berpikir kritis peserta didik. Lebih lanjut, penelitian Rosiah (2014) juga menunjukkan bahwa model pembelajaran cooperatif tipe jigsaw berpengaruh terhadap kemampuan berpikir kritis siswa pada materi kingdom animalia. Selain itu, penelitian Sudin (2017) menunjukkan bahwa model pembelajaran RQA berpengaruh terhadap kemampuan berpikir kritis siswa kelas VIII Sekolah Menengah Pertama Negeri 02 Sintang 
Vol. 04, No. 01 : Hal. 9 - 15

Februari 2019

pokok bahasan sistem pernapasan pada manusia.

Dilihat dari hasil analisis indikator kemampuan berpikir kritis menunjukan hasil yang bervariasi dari masing-masing indikator. Hasil analisis indikator

kemampuan berpikir kritis selengkapnya dapat dilihat pada lampiran terlampir untuk rekapitulasi data hasil tes indikator kemampuan berpikir kritis secara umum dapat dilihat pada Tabel 3.

Tabel 3. Nilai Indikator Kemampuan Berpikir Kritis Siswa

\begin{tabular}{llcccc}
\hline \multirow{2}{*}{ Ino } & Indikator Berpikir Kritis & \multicolumn{2}{c}{ Kelas Eksperimen } & \multicolumn{2}{c}{ Kelas Kontrol } \\
\cline { 3 - 5 } & & Pretest & Posttest & Pretest & Posttest \\
\hline 1 & Memberikan argumen & 55,17 & 82,06 & 59,25 & 98,14 \\
2 & Memutuskan dan & 38,00 & 47,00 & 38,00 & 62,03 \\
& melaksanakan & & & \\
3 & Induksi & 25,00 & 100 & 29,00 & 84,25 \\
4 & Merumuskan masalah & 63,00 & 100 & 61,11 & 100 \\
5 & Deduksi & 27,00 & 78,00 & 30,00 & 46,29 \\
6 & Evaluasi & 21,00 & 84,00 & 33,33 & 64,00 \\
\hline
\end{tabular}

Hasil uji hipotesis kemampuan berpikir kritis siswa dapat dilihat pada Tabel 4. Hasil Uji Hipotesis pada Tabel 4 menunjukkan nilai probabilitas pretest kelas eksperimen dan kelas kontrol sebesar 0,504 dan lebih besar dari nilai alpha 0,05 sehingga tidak terdapat perbedaan berpikir kritis siswa antara kelas eksperimen dan kelas kontrol. Selajutnya, hasil posttest menunjukkan nilai probabilitas sebesar 0,000dan lebih kecil dari nilai alpha 0,05 maka terdapat perbedaan berpikir kritis siswa antara kelas eksperimen dan kelas kontrol pada pengukuran akhir (posttest). Kelas eksperimen mengalami peningkatan yang lebih tinggi dibandingkan kelas kontrol.

Tabel 4. Hasil Uji Hipotesis

\begin{tabular}{cccc}
\hline Jenis Tes & Sig. (2- tailed) & $\boldsymbol{\alpha}$ & Kesimpulan \\
\hline $\begin{array}{c}\text { Pretest kelas eksperimen } \\
\text { dan kelas kontrol }\end{array}$ & 0,504 & 0,05 & H0 diterima \\
\hline $\begin{array}{c}\text { Postest kelas eksperimen } \\
\text { dan kelas kontrol }\end{array}$ & 0,000 & 0,05 & H1 diterima \\
\hline
\end{tabular}

Berdasarkan uji hipotesis dapat disimpulkan bahwa model pembelajaran JiRQA lebih mampu meningkatkan kemampuan berpikir kritis siswa. Hal ini disebabkan karena model pembelajaran kooperatif tipe JiRQA merupakan model yang mampu memaksa siswa dalam membaca, membuat rangkuman, membuat pertanyaan, dan menjawab pertanyaan sendiri berdasarkan pernyataan yang telah disusun.

Tahapan-tahapan pada pembelajaran JiRQA seperti menjadi ahli di bidangnya, akan mampu menuntut peserta didik biologi untuk lebih banyak belajar berpikirsecara mandiri dan berkelompok dalam menyelesaikan permasalahan yang diberikan (Bustami, 2017b). Aktivitas belajar tersebut akan mendorong para pebelajar menjadi pebelajar mandiri. Menurut Corebima (2006), jelas terlihat bahwa pada self regulated learning para pebelajar dikondisikan terus menerus berpikir dan berpikir.

Kegiatan diskusi dalam kelompok ahli dan asal dalam pembelajaran JiRQA mampu meningkatkan kemampuan berpikir kritis. Menurut Bustami (2017b), kegiatan diskusi dalam pembelajaran JiRQA akan mampu memberikan kesempatan kepada 
Vol. 04, No. 01 : Hal. 9 - 15

Februari 2019

E-ISSN: 2597-9833

peserta didik untuk saling berargumentasi, melakukan tanyajawab, dan menarik kesimpulan terhadap materi yang didiskusikan. Kegiatan berargumentasi, melakukan tanyajawab, dan menarik kesimpulan terhadap materi yang didiskusikan mampu mengasah kemampuan berpikir kritis siswa. Disisi lain, kegiatan tutor sebaya dalam pembelajaran JiRQA mampu membuat peserta didik berpikir lebih banyak sehingga akan melatih kemampuan menganalisis dan menginterpretasi terhadap materi yang sedang dibahas.

\section{SIMPULAN DAN SARAN}

Berdasarkan analisis data dan pembahasan maka dapat disimpulkan bahwa penggunaan Model pembelajaran kooperatif tipe JIRQA mampu meningkatkan kemampuan berpikir kritis siswa biologi. Berdasarkan hasil penelitian menunjukkan bahwa terdapat pengaruh yang signifikan pada kemampuan berpikir kritis antara kelas ekperimen dan kelas kontrol pada materi pertumbuhan dan perkembangan pada tumbuhan. Hasil nilai rerata kemampuan berpikir kritis siswa pada kelas eksperimen sebesar 79,41 dan kelas kontrol sebesar 71,00. Adapun saran yang dapat disampaikan, yaitu bagi guru, diharapkan mampu untuk mempraktekkan atau menerapkan model pembelajaran kooperatif tipe JiRQA pada pembelajaran IPA, sehingga kemampuan berpikir kritis siswa lebih meningkat. Bagi peneliti selanjutnya, diharapkan dapat menggunakan artikel ini dengan baik sebagai bahan acuan atau pembanding dalam penelitian yang serumpun dengan penelitian ini. Selain itu dapat melakukan penelitian pada sekolah-sekolah lain dengan memberikan inovasi baru terhadap model pembelajaran kooperatif tipe JiRQA

sehingga kemampuan berpikir kritis siswa meningkat secara maksimal.

\section{RUJUKAN}

Ariyanti, N.W.P., Lasmawan, I.W. \& Dantes, N. (2013). Pengaruh Model Pembelajaran Kooperatif Tipe Jigsaw terhadap Kemampuan Berpikir Kritis dan Prestasi Belajar Siswa dalam Pembelajaran IPS Pada Siswa Kelas IV SD Cipta Dharma Denpasar. e-Journal Program Pascasarjana Universitas Pendidikan Ganesha, 3.

Bustami, Y., Syafruddin, D., \& Afriani, R. (2018). The Implementation of Contextual Learning to Enhance Biology Students' Critical Thinking Skills. Jurnal Pendidikan IPA Indonesia, 7(4), 451-457.

Bustami, Y. (2017a). Pengaruh Strategi Pembelajaran JiRQA Terhadap Kemampuan Kognitif, Kemampuan Berpikir Kritis, \& Sikap Sosial Mahasiswa Multietnis Pada Perkuliahan Zoologi di STKIP Persada Khatulistiwa Sintang. Disertasi tidak diterbitkan. Malang: Pasca Sarjana Universitas Malang.

Bustami, Y. (2017b). The Empowerment of Critical Thingking Skills and Social Attitudes: Multiethnic Studentsin Higher Education. Jerman: Editions University Europeennes.

Corebima, A.D. (2006). Pembelajaran Biologi yang Memberdayakan Kemampuan Berpikir Siswa. Makalah disajikan pada Pelatihan Strategi Metakognitif pada Pembelajaran Biologi untuk Guru-Guru Biologi SMA di Kota Palangkaraya, 23 Agustus 2006.

Efendi, N \& Rokayana, N.W.(2017). Analisis Keterampilan Berpikir Kritis Siswa SMP Pada Mata Pelajaran IPA Ditinjau dari Gaya Belajar Visual. Science EducationJournal, 1(2): 85-91. Jumaisyaroh. T, Napitupulu, E.E \& Hasratuddin. (2014). Peningkatkan Kemampuan Berpikir Kritis Matematis \& Kemandirian Belajar Siswa SMP 
Vol. 04, No. 01 : Hal. 9 - 15

Februari 2019

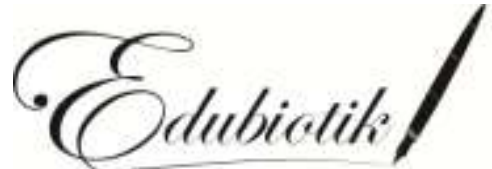

P-ISSN: 2528-679X

E-ISSN: 2597-9833

melalui Pembelajaran Berbasis

Masalah. Jurnal Kreano, 5(2): 158-16.

Liliasari. (2003). Peningkatan Mutu Guru dalam Keterampilan Berpikir Tingkat Tinggi melalui Model Pembelajaran Kapita Selekta Kimia Sekolah Lanjutan. Jurnal Pendidikan Matematika dan Sains. III: 174 -181.

Rosiah.(2014).Pengaruh pembelajaran cooperatif tipe jigsaw terhadap kemampuan berpikir kritis siswa materi kongdom animalia.Skripsi tidak diterbitkan. Sintang: STKIP Persada Khatulistiwa Sintang.

Sudin. (2017). Pengaruh Model Reading, Questinong, Answering (RQA) Terhadap Kemampuan Berpikir Kritis Siswa Kelas VIII Sekolah Menengah Pertama (SMP) NEGERI 02 Sintang Pada Pokok Bahasan Sistem Pernapasan Manusia Tahun Pelajaran 2017/2018.Skripsi Tidak Diterbitkan. Sintang: STKIP Persada Khatulistiwa Sintang.
Suparmi. (2012). Pembelajaran Kooperatif dalam Pendidikan Multikultural. Jurnal Pembangunan Pendidikan: Fondasi dan Aplikasi, 1(1): 108-118.

Trikasari, K. M. (2016). Penerapan Model Pembelajaran Group Investigation (GI) Terhadap Kemampuan Pemecahan Masalah Siswa Pada Materi Sistem Pencernaan Pada Manusia. Skripsi Tidak Diterbitkan. Sintang: STKIP Persada Khatulistiwa Sintang.

Zubaidah. S. (2016). Keterampilan Abad ke-21 Keterampilan yang diajarakan melalui Pembelajaran. Buku yang disajikan dalam Seminar Nasional Pendidikan dengan Tema Isu-isu Strategi Pembelajaran MIPA ABAD 21, Prosiding di Program Studi Pendidikan Biologi STKIP Persada Khatulistiwa Sintang 10 Desember 2016. 